\section{More questions than answers}

\section{Bethesda, Maryland}

SEEKING to interject a little reason and experience into what has become a heated international fracas over the patenting of human genes, the National Institutes of Health (NIH) last week asked a dozen patent and technology-transfer experts to argue the issues in public. Fourteen hours of debate later, the experts appeared to have vindicated $\mathrm{NIH}$ for launching the controversy, even if they were no closer to agreeing whether it is desirable, or even possible, to patent the genetic sequences under question.

If there were still doubt that the question of whether unidentified gene fragments should be patentable has become the most contentious scientific debate of the day, the NIH meeting should have banished it. A full house of observers sat through a day and half a night of esoteric argument on the subtleties of international patent law until NIH had to shut the building for the night. But many left wondering just what to conclude. While scientists had argued that the debate is essentially legal, and lawyers had explained that it is really all up to the US patent office, one could not help noticing that the audience included several patent office officials asking questions and taking careful notes.

Since news emerged last month that NIH had quietly filed a patent application for some $350 \mathrm{cDNA}$ fragments of unknown function and physical significance, the agency has been accused of breaking the international genome project's code of free data exchange, as well as of undermining US biotechnology industry by attempting to put frivolous licensing hurdles in the path of commercialization (see Nature 353, 485; 10 October, 1991). Although most of the industry representatives and lawyers who spoke out at the meeting thought that patents on such gene fragments would do industry more harm than good, they also noted that much the same had been said of the first attempts to patent recombinant DNA technology in the 1970s; now those patents are considered the foundations of the biotechnology industry.

Acknowledging that no one at this point seems to know what to make of the NIH application, NIH director Bernadine Healy announced that the next move would be made by her administrative superiors; Louis Sullivan, secretary of the department of Health and Human Services, which runs NIH, will make a policy decision on filing future cDNA patents. But before he does, the White House will be asked for an opinion. Healy said that the White House Office of Management and Budget, the Office of Science and Technology Policy and possibly the Council on Competitiveness will all participate in making gene-patenting policy.

Continuing controversy on this issue may not bode well for future harmony in the genome project, but it does appear to take the immediate pressure off NIH. When the news of NIH's application first broke last month, many researchers blamed both the agency and Craig Venter, the NIH scientist who discovered the genes, for filing the application in the first place. Now that industry and legal experts have turned out to be divided on the issue themselves, most of the participants agreed that
NIH had been right all along in taking the safe route: given the uncertainty in the viability and implications of gene patents, letting the sequences appear in the public domain without patent protection would have been tantamount to legal "malpractice", said patent expert Harold Wegner of George Washington University.

Given the lack of consensus on the merits of gene patents - or even agreement on the application of standard patent law to this case - some lawyers at the conference argued for special patent of fice treatment for gene patent applications until the issue is settled. S. Leslie Misrock, a partner in the patent law firm Pennie and Edmonds, proposed that the patent office accept cDNA applications on a special reduced-fee basis until it had decided whether they could be granted. If cDNA patents are approved in principle, Misrock suggested, the patent office could allow each applicant the opportunity to pay the full fee and have his application examined for approval as usual.

Lawyers at the conference noted that the US Congress has recently raised another issue that appears to bear on the controversy: that of the extent to which scientists are entitled to use patented materials in the course of their research, without paying royalties. Long-standing patent law allows for free use if the researcher has only "philosophical interest" in the patented material. But in a bill introduced last year, the House judiciary committee questioned the meaning of that wording in modern laboratories, where researchers are encouraged to turn every invention into a marketable product. The committee plans to hold a hearing on the issue before the end of the year.

Christopher Anderson

\title{
$A$ battle as old as the nation
}

\section{Washington}

BEHIND the current gene patent controversy lies a debate that has raged since Thomas Jefferson introduced the first US intellectual property laws nearly two hundred years ago: When are patents good for industry and investment, and when do they just get in the way?

That question is especially contentious in research, where patent procedures often clash with ideals of free exchange of scientific data. US patent applications are by law secret and can take years to be approved; during that period applicants may refuse to publish or share the data for fear of losing all rights if the patent is not granted.

Until a 1980 Supreme Court decision allowing the patenting of oil-eating bacteria, the United States took the moral high ground: it put all government research (such as that done by the $\mathrm{Na}$ tional Institutes of Health (NIH) and the laboratories of the Department of Energy) in the public domain. This was despite some very good evidence that the policy was doing the US taxpayer few favours a study conducted in the 1960 s found that no government invention to date had ever been commercialized. During World War II, the government itself had to develop penicillin to combat infections in troops because no company would invest the money developing an antibiotic it could not own.

Universities also wrestle with balanc ing science and commerce. At a technology transfer meeting at NIH last week, Hoffman-LaRoche patent attorney George Gould noted that until the 1970 s Harvard University had a policy of never seeking patents for the inventions of its scien tists. "They changed their mind when they realized that 100 years of science from the best minds in medicine had never turned out a product," Gould recalled.
Although most US research universities now have technology transfer offices to encourage patents, a new spectre - product liability - has arrived to cloud the issue. Reid Adler, NIH's technology transfer director, reported that increasingly aggressive litigation to recover damages in medical-product liability cases is starting to raise fears throughout the patent chain. If a university licenses its technology to a small company to manufacture a product that eventually becomes the subject of a lawsuit, a plaintiff may choose to sue the university - "going for the endowment", as Adler puts it - as well as the company. In the face of such prospects, some universities are starting to reconsider the benefits of technology transfer, especially to start-up companies. "They're saying, 'We'd like to license the technology, but we're afraid of losing the football team,'" Adler said. 